\title{
Гонартроз: поширеність та диференційний підхід до ендопротезування
}

\author{
Т.І. Осадчук', А.В. Калашніков' ${ }^{1}$ О.В. Хиць ${ }^{2}$ \\ 'ДУ «Інститут травматології та ортопедії НАМН України», Київ, Україна \\ ${ }^{2}$ КНП «Консультативно-діагностичний центр» Подільського району, Філія № 2, Київ, Україна
}

Анотація. Гонартроз - одна з найактуальніших та складних проблем сучасної ортопедії, яка уражує понад 250 млн осіб у всьому світі, $\epsilon$ провідною причиною вираженого больового синдрому в осіб похилого віку, призводить до втрати працездатності, інвалідизації та асоційована з підвищеним ризиком смертності. На сучасному етапі тотальне ендопротезування колінного суглоба $є$ найбільш ефективним та загальновизнаним методом лікування гонартрозу на кінцевій стадії захворювання. Інших ефективних методів лікування пацієнтів із остеоартритом колінного суглоба на цій стадії хвороби просто не існує. У статті розглянуто особливості проведення хірургічного лікування, вибір ендопротезу та наведено власний досвід успішного тотального ендопротезування колінного суглоба у пацієнтів 3 гонартрозом.

Ключові слова: гонартроз, остеоартрит, хронічний больовий синдром, остеоартроз, ендопротезування, тотальне ендопротезування, артропластика, артропластика колінного суглоба, артроз.

\section{Остеоартрит як ключова \\ причина інвалідизації}

На сучасному етапі поширеність дегенеративно-дистрофічних захворювань кістково-суглобового апарату продовжує неухильно зростати в усьому світі, що пов'язано зі збільшенням тривалості життя населення, гіподинамією, надмірною масою тіла і ожирінням та рядом інших факторів, які включають травму і деформацію суглобів (таблиця). Так, успіхи медицини привели до того, що сьогодні відмічається значне збільшення кількості осіб похилого і старечого віку. Відповідно до статистичних даних у 2018 р. вперше за історію кількість осіб віком > 65 років перевищила кількість дітей віком <5 років у всьому світі і, за оцінками експертів, до 2050 р. очікується збільшення на $22 \%$ осіб віком $>60$ років [1]. Епідеміологічні дані свідчать, що з усіх найбільш поширених хронічних захворювань людини м'язово-скелетна патологія - ключова причина інвалідизації населення, особливо серед осіб віком 40-65 та $\geq 65$ років. При цьому в контексті патології м'язово-скелетної системи провідною причиною інвалідизації та зниження якості життя $\epsilon$ саме остеоартрит (ОА) [2]. Так, згідно з результатами дослідження E. Nuesch та співавторів (2011) хронічний больовий синдром у суглобах нижніх кінцівок призводить до інвалідності та підвищеного ризику смертності від усіх причин [3]. За даними телефонного опитування 46394 респондентів з 16 європейських країн, 19\% осіб страждають від вираженого хронічного болю з інтенсивністю не менше 5 балів за 10-бальною візуальною аналоговою шкалою, а найпоширенішою причиною хронічного больового синдрому $\epsilon$ саме ОА (рис. 1) [4].

Поширеність ОА в популяції становить 6,43\% і корелює з віком, досягаючи $13,9 \%$ у осіб віком $>45$ років і $97 \%$ у осіб віком $>60$ років. І якщо раніше дегенеративно-дистрофічні захворювання суглобів, зокрема ОА, відмічали в осіб похилого віку, то на сьогодні близько $30 \%$ хворих на ОА віком $>40$ років. У популяційних дослідженнях частота та поширеність захворювання зростають у 2-10 разів за період 30-65 років і продовжують зростати з віком. Окрім того, поширеність ОА має також очевидні статеві відмінності. До 50-річного віку поширеність ОА зазвичай вища у чоловіків, тоді як серед осіб віком $>50$ років ОА частіше відмічають у жінок. В останні роки проблемі ОА приділяють все більшу увагу через виявлення складних і різноманітних механізмів його розвитку, збільшення поширеності і високу інвалідизацію.

Раніше ОА сприймали як хворобу «wear and tear», що $\epsilon є д и-$ ним наслідком деградації хряща без участі інших суглобових клітин та тканин. Ця гіпотеза базувалася на відомих на той час факторах ризику ОА, які включали травму, деформацію суглобів, нестабільність, механічні впливи на суглоби, надмірну масу тіла, особливо для опорних суглобів та старіння [5]. Однак на сучасному етапі парадигма ОА повільно змінюється завдяки важливим відкриттям в останні 20 років [6, 7]. Роль запалення в розвитку та прогресуванні ОА тривалий час заперечувалася, оскільки суглобовий хрящ $є$ неваскуляризованою тканиною. Однак у 1972 р. M.T. Corvol та співавтори створили клітинну культуру хондроцитів, що стало революцією в розумінні патогенезу ОА, оскільки дозволило розглядати захворювання як наслідок клітинних подій [8]. У 1991 p. J.P. Pelletier та співавтори встановили роль хондроцитів у підтримці гомеостазу хрящової тканини, які за певних обставин здатні виділяти численні медіатори - простагландини, цитокіни та хемокіни, які можуть збільшувати продукцію матриксних металопротеїназ хондроцитами (рис. 2) [9, 13]. Саме ці відкриття зумовили перші кроки у створенні «запальної» парадигми ОА [10]. Довгий час вважалося, що синовіт $є$ патогномонічним симптомом ревматоїдного артриту, проте значна кількість досліджень продемонструвала, що синовіт різного ступеня ви-

\begin{tabular}{|c|c|}
\hline & ОА: вроджені, набуті та зовнішні фактори ризику \\
\hline \multirow[t]{2}{*}{ Вроджені } & Жіноча стать \\
\hline & Етнічна приналежність \\
\hline \multirow[t]{5}{*}{ Набуті } & Надмірна маса тіла \\
\hline & Похилий вік \\
\hline & Зміни гормонального статусу \\
\hline & Порушення розвитку \\
\hline & Хірургічне втручання на суглобах \\
\hline \multirow[t]{4}{*}{ Зовнішні } & Професійні шкідливості \\
\hline & Надмірне навантаження на суглоби \\
\hline & Заняття спортом \\
\hline & Травма суглобів \\
\hline
\end{tabular}

Рисунок 1 ОА як ключова причина хронічного больового синдрому

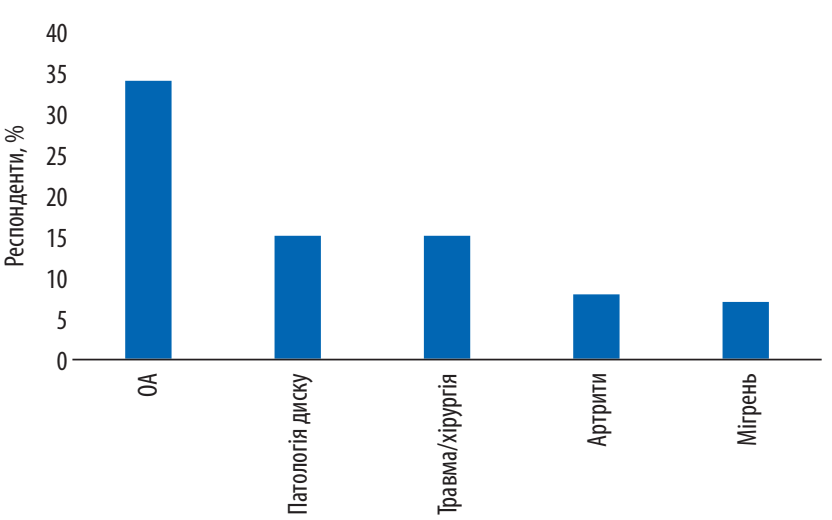


раженості відмічають також при ОА, крім того, його інтенсивність корелює з прогнозом захворювання [11].

На сьогодні відомо, що при ОА у патологічний процес залучаються всі структури суглоба, зокрема і субхондральна кістка [12]. Суглоб розглядають не як сукупність кісткових суглобових поверхонь, хрящових структур, синовіальної рідини, суглобової капсули і періартикулярного апарату, а як єдиний орган з властивими йому запальними, нейротрофічними, імунними, метаболічними та функціональними складовими. Сьогодні ОА вважається органним захворюванням, а з урахуванням ураження різних суглобових груп - поліорганним.

Рисунок 2 Патогенез ОА

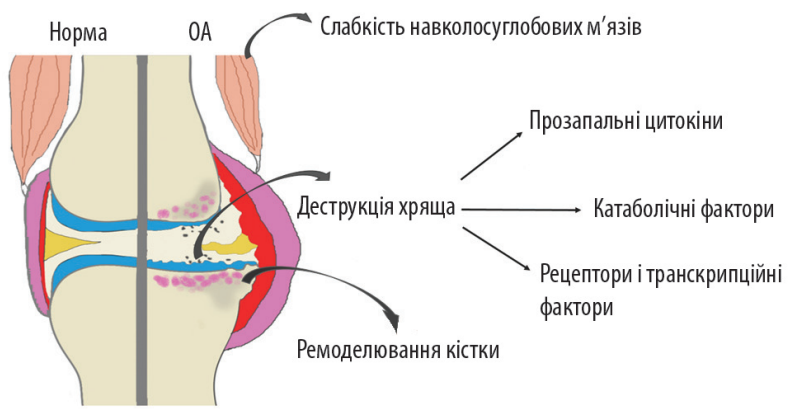

Суперечка про можливе лише механічне пошкодження суглобового хряща була фактично припинена після відкриття внутрішньоклітинного механосигналінгу. Виявилося, що будь-яке механічне напруження, наприклад розтягнення, стиснення, компресія, гідростатичний тиск, призводить до збудження механорецепторів, розташованих на поверхні клітин суглоба. Ці сигнали можуть призвести до надмірної експресії прозапальних медіаторів [14]. Локальна продукція прозапальних цитокінів, таких як простагландини, цитокіни, хемокіни, в хондроцитах і клітинах субхондральної кістки здатна також впливати на ініціацію та посилення інших вікозалежних та метаболічних захворювань. Недарма ОА відносять до захворювань із одним із найвищих індексів коморбідності.

Виходячи 3 того, що з огляду на відсутність кровопостачання та іннервації хрящ сам по собі не здатний ініціювати запальні реакції або біль принаймні на ранніх стадіях захворювання, відповідно, джерелом болю $\epsilon$ зміни в нехрящових складових суглоба, таких як суглобова капсула, синовіальна оболонка, субхондральна кістка, зв'язки та періартикулярні м'язи [15]. У міру розвитку хвороби ці структури з різною швидкістю залучаються до патологічного процесу, зумовлюючи патологічне ремоделювання кістки, утворення остеофітів, ослаблення періартикулярних м'язів, слабкість зв'язок та синовіальний випіт.

\section{Гонартроз: сучасні принципи лікування}

Серед ОА великих суглобів однією з найактуальніших проблем $€$ ураження колінного суглоба - гонартроз, що $€$ найпоширенішою формою ОА, яку часто виявляють в осіб віком >50 років. Гонартроз уражує $>250$ млн осіб у всьому світі і $\epsilon$ провідною причиною вираженого больового синдрому в осіб похилого віку, який призводить до втрати працездатності та підвищення смертності. Дані літератури свідчать, що гонартроз реєструють у 50,6-54,5\% випадків серед хворих на дистрофічні захворювання великих суглобів нижньої кінцівки, і у $86 \%$ випадків - в осіб працездатного віку, а в 6,5-14,6\% випадків він призводить до інвалідності [16]. Наявні дані свідчать, що гонартроз $\epsilon 11$-м фактором глобальної втрати працездатності, частота захворювання зросла на 64\% з 1994 до 2010 р.

Хронічний больовий синдром, зниження якості життя хворих, а також високий ризик інвалідизації та смертності визначають потребу в застосуванні ефективних методів лікування гонартрозу.

Вибір лікування ОА повинен базуватися на таких терапевтичних схемах, які здатні допомогти, а не нашкодити пацієнту, спричинивши прогресування деградаційних процесів у суглобовому хрящі та навколишніх тканинах. У 2019 р. опубліковані рекомендації Європейського товариства з вивчення клінічних і економічних аспектів остеопорозу і остеоартрозу (European Society for Clinical and Economic Aspects of Osteoporosis, Osteoarthritis and Musculoskeletal Diseases - ESCEO) щодо менеджменту пацієнтів із ОА колінного суглоба, в яких лікування ОА включає 4 кроки:

1-й крок: застосування хондропротекторів та нестероїдних протизапальних препаратів (НПЗП);

2-й крок: періодичне або тривалими курсами застосування пероральних НПЗП;

3-й крок: короткі курси слабких опіоїдів, дулоксетин та внутрішньосуглобові ін'єкції (глюкокортикостероїди або гіалуронова кислота);

4-й крок: у разі виражених симптомів та низької якості життя рекомендовані тотальне ендопротезування суглобів або часткова артропластика суглобів.

\section{Особливості тотального ендопротезування колінного суглоба при гонартрозі}

На сучасному етапі наявна значна кількість міжнародних організацій та професійних товариств, які постійно займаються вивченням та аналізом проблем менеджменту пацієнтів із ОА та періодично представляють лікарям гайдлайни з лікування цієї патології. I хоча у кожного товариства свій погляд на проблему ОА, всі вони єдині в одному: якщо фармакологічна терапія неефективна, у пацієнта наявний виражений хронічний больовий синдром і значно знижена якість життя, доцільним $\epsilon$ проведення оперативного лікування. Тотальне ендопротезування або однокомпонентна артропластика колінного суглоба на сучасному етапі $\epsilon$ одними 3 найефективніших та загальновизнаних методів лікування вираженого гонартрозу, які показані не лише при неефективній консервативної терапії, а й за наявності протипоказань до коригуючої остеотомії та неефективності артроскопічного лікування. Ключова мета хірургічного лікування полягає в усуненні або зниженні інтенсивності хронічного больового синдрому, поліпшенні функції ураженого суглоба та опороспроможності нижньої кінцівки і, як наслідок, поліпшення якості життя пацієнта [17].

ESCEO настійно рекомендує проводити ендопротезування колінних суглобів у пацієнтів з гонартрозом на кінцевій стадії захворювання. Інших ефективних методів лікування пацієнтів із ОА на цій стадії хвороби просто не існує. Дані літератури свідчать, що тотальне ендопротезування колінного суглоба дозволяє отримати задовільні результати у >90\% випадків на період від 10 до 20 років. В останні десятиліття відзначають збільшення кількості виконаних операцій із заміни суглобів. Тотальне ендопротезування суглоба має кращу довгострокову ефективність, що пов'язано зі зростанням частоти ендопротезування у світі. Наприклад, у 1990 р. у США на 100 тис. осіб виконували 51 операцію ендопротезування колінного суглоба, у 2002 р. - вже 136, а у 2012 р. - 155. Сьогодні у світі щорічно виконують до 1,5 млн операцій з тотального ендопротезування і, за оцінками, цей показник підвищуватиметься з кожним роком та досягне до 2030 р. 3 млн операцій на рік, що пов'язано 3 технічним прогресом, розширенням показань до ендопротезування та збільшенням тривалості життя популяції $[18,19]$. Однак прогресивне збільшення кількості оперативних втручань неминуче пов'язане зі зростанням кількості ускладнень, включно з інфекційними ускладненнями. Статистичні дані свідчать, що в останні роки частота ревізійних операцій на колінному суглобі зросла з 4,7 на 100 тис. населення на рік до 19,8 у 2012 р., і в мабутньому прогнозується 60 ревізійних операцій на 100 тис. осіб на рік [20].

При первинному ендопротезуванні колінного суглоба більшість хірургів зазвичай надають перевагу незв'язаним і частково пов'язаним моделям ендопротезів, досвід застосування яких підтвердив їх високу ефективність як у відновленні функції суглоба, так і в плані тривалості і передбачуваності віддалених результатів. Однак деякі дослідження вказують на необхідність імплантації шарнірних ендопротезів при первинному і ревізійних втручаннях, які дозволяють стабілізувати суглоб при неспроможності колатеральних зв'язок і компенсувати великі дефекти стегнової і великогомілкової кісток. 
Триполюсні, або тотальні, ендопротези залежно від вираженості механічного зв'язку між стегновим і великогомілковим компонентами умовно поділяють на:

- незв'язані (unconstrained): потребують збереження під час операції обох хрестоподібних зв'язок і нормальної функції колатеральних;

- частково пов'язані (semiconstrained): дозволяють у поєднанні з обмеженою мобілізацією зв'язок і капсули суглоба виправляти тяжкі, фіксовані деформації (обмеження розгинан-

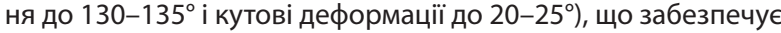
відновлення нормальної осі кінцівки і стабільності суглоба. По відношенню до задньої хрестоподібної зв'язки вони діляться на ендопротези, де треба виконувати ії збереження і ендопротези, де треба виконувати її заміщення;

- повністю пов'язані ендопротези (fully constrained): забезпечують здійснення згинання, розгинання і ротацію, цілком обмежуючи приведення та відведення. Конструктивно ці імплантати з'єднуються між собою за допомогою шарніра, петльового механізму або іншим способом [21].

у 1960-х роках обмежене клінічне застосування мали саме шарнірні ендопротези колінного суглоба. Однак простий петльовий шарнір не відтворював складне поєднання рухів, які виникають у колінному суглобі під час ходьби, що пов'язано з тим, що положення поперечної осі, навколо якої відбуваються згинання і розгинання, постійно змінюється, описуючи криву у формі коми, - так звана поліцентрична ротація. Згинання і розгинання супроводжуються котінням і ковзанням між виростками стегнової і великогомілкової кісток, а також відведенням/приведенням та внутрішньою/зовнішньою ротацією [22]. Саме тому шарнірні моделі ендопротезів мають ряд істотних недоліків, які включають:

- високий рівень асептичного розхитування в найближчі роки після імплантації (16-50\%);

- велику кількість інфекційних ускладнень (8-15\%);

- необхідність у проведенні великої резекції кісткової тканини i, як наслідок, хронічний больовий синдром, значні кісткові дефекти, що асоційовані зі значними труднощами при проведенні ревізійних операцій $[23,24]$.

Враховуючи вищезазначені дані, перевагу слід надавати непов'язаним і частково пов'язаним моделям ендопротезів. Повністю пов'язані ендопротези колінного суглоба за ступенем свободи рухів можна розділити на дві групи: петльові, які допускають лише згинання та розгинання гомілки, та шарнірні, які, окрім згинання та розгинання, забезпечують також зовнішню та внутрішню ротації гомілки. Показання до застосування шарнірних ендопротезів включають неможливість збалансувати згинально-розгинальний проміжок за формою і розміром при неспроможності колатеральних зв'язок, анкілозі колінного суглоба, ревізійних втручаннях після раніше імплантованих шарнірних імплантатів та онкологічні ураження стегнової і великогомілкової кісток, що потребують повної резекції метаепіфізів. У всіх інших випадках перевагу необхідно надавати непов'язаним і частково пов'язаним видам ендопротезів.

В останні роки увага прикута до досліджень, спрямованих на покращення характеристик пари тертя «метал-поліетилен», що традиційно застосовують в ендопротезах колінного суглоба [25]. Результати нещодавнього дослідження, в якому використовували тривимірний симулятор, визначили, що застосування перехресно-пов'язаного високомолекулярного поліетилену з додаванням вітаміну Е достовірно зменшує зношуваність вкладиша порівняно зі стандартним високомолекулярним поліетиленом [26]. Результати іншого дослідження визначили, що застосування цього матеріалу має як потенційну перевагу у вигляді підвищення зносостійкості, так і ряд недоліків, які включають утворення більш дрібних і потенційно більш активних щодо остеолізу продуктів стирання, підвищений ризик перелому заднього стабілізатора і руйнування механізму фіксації вкладиша через меншу механічну міцність матеріалу [27].

Ряд досліджень висвітлює особливості функціонування in vivo та in vitro альтернативних пар тертя. У дослідженні A. Essner та співавторів (2011), в якому порівнювали за допомогою симулятора моделі ендопротезів Oxinium Genesis II (з керамічним покриттям) i Triathlon i Triathlon X3, з'ясували, що дизайн імплантату чинить більший вплив на зношуваність компонентів, ніж матеріали, з яких він виготовлений [28]. У дослідженні С. Нuј та співавторів (2011), які провели рандомізоване контрольоване порівняльне клінічне дослідження 5-річних результатів ендопротезування колінного суглоба з використанням стегнових компонентів з оксиду цирконію і кобальт-хромового сталевого сплаву, продемонстрували, що обидва компоненти показали ідентичні клінічні, суб'єктивні та рентгенологічні результати [29]. Результати дослідження D. Veigl та співавторів (2011) не свідчать про будь-які значимі відмінності між застосуванням кобальт-хромового і керамічного типів стегнових компонентів через 7 років після ендопротезування [30]. Таким чином, дослідження останніх років не виявили достовірної різниці у віддалених результатах ендопротезування з використанням повністю поліетиленових та модульних (з металевою основою) великогомілкових компонентів. Враховуючи меншу вартість повністю поліетиленових великогомілкових компонентів, їх широке застосування $\epsilon$ виправданим для зниження витрат системи охорони здоров'я [31].

На сучасному етапі процес розробки геометрії компонентів ендопротеза колінного суглоба не стоїть на місці та постійно удосконалюється. R. Willing i I.Y. Kim (2011) у роботі, яка присвячена оптимізації дизайну штучних суглобів, зазначають, що сьогодні не існує систематичного методу, спрямованого на визначення оптимальної форми компонентів ендопротеза. Автори у своєму дослідженні пропонують новий дизайн стегнового компонента й поліетиленового вкладиша, відмінними особливостями якого $\epsilon$ малий радіус кривизни стегнового компонента у фронтальній і сагітальній площинах із дещо більшим радіусом кривизни латерального виростка [32]. Порівняно з доступними комерційними зразками ендопротез R. Willing i I.Y. Kim покращує стабільність на $81 \%$ і амплітуду згинання — на 12,6\% (до $143^{\circ}$ ).

Також важливо при ендопротезуванні використовувати гендерноспецифічні стегнові компоненти. Результати проспективного дослідження S.P. Guy та співавторів (2012), в якому провели стандартизоване вимірювання дистального відділу стегнової кістки та оцінили розміри стандартного і «жіночого» стегнових компонентів у межах однієї системи імплантатів, продемонстрували, що між чоловіками та жінками наявні значні відмінності в частоті й величині нависання стегнового компонента над кістковою основою [33]. Визначено, що при використанні стандартного стегнового компонента нависання переднього фланця на $>2$ мм виявлено у $>80 \%$ жінок, нависання в медіально-латеральному розмірі $>2$ мм - у 96\% жінок, тоді як у чоловіків ці явища були лише у $2 \%$ випадків. Таким чином, результати цього дослідження свідчать, що використання гендерноспецифічного стегнового компонента дозволяє знизити ймовірність його нависання.

\section{Диференційний підхід до ендопротезування колінного суглоба}

У 2017 р. опубліковані результати дослідження Г.В. Гайко та співавторів, проведеного на базі ДУ «Інститут травматології та ортопедії НАМН України» (Київ), на підставі яких розроблено диференційний підхід до ендопротезування колінних суглобів залежно від тяжкості ураження суглоба у хворих на деформуючий гонартроз 3-4-ї стадії (згідно з класифікацією Kellgren \& Lawrence) [34, 35]. У дослідження включено дані 324 операцій ендопротезування колінного суглоба у хворих на гонартроз віком $62 \pm 14$ років (жінки $-82,5 \%$, чоловіки $-17,5 \%$.).

При виборі виду ендопротеза у хворих на гонартроз враховували наступні ознаки:

- рентгенографічна стадія ОА;

- вік пацієнта;

- наявність асептичного некрозу одного з виростків стегнової кістки;

- величина дефекту кісткової тканини медіального/латерального виростка великогомілкової кістки;

- величина згинальної контрактури; 
- наявність повної неспроможності бокових стабілізаторів колінного суглоба.

Відповідно до отриманих результатів пацієнтам віком <60 років з гонартрозом, ускладненим асептичним некрозом медіального виростка стегнової кістки, доцільно виконувати унікондилярне ендопротезування. За наявності згинальної контрактури в колінному суглобі $>15^{\circ}$ рекомендоване застосування моделі ендопротеза без збереження задньої хрестоподібної зв'язки. При наявності дефекту медіального/латерального виростка великогомілкової кістки $<5$ мм рекомендована пластика кістковим цементом, тоді як наявність дефекту > 10 мм потребує застосування кісткової пластики та використання ендопротеза з тібіальним подовжувачем. У хворих на гонартроз зі значним пошкодженням зв'язкового апарату колінного суглоба та при наявності повної неспроможності бокових стабілізаторів рекомендоване тотальне ендопротезування цільнозв'язаним ендопротезом. Цей диференційний підхід до ендопротезування колінних суглобів у хворих на гонартроз дозволяє отримати 99\% позитивних результатів [36].

Далі наводимо власний досвід успішного ендопротезування колінного суглоба у пацієнтів з гонартрозом.

\section{Клінічний випадок № 1}

Пацієнтка Л., 80 років. Звернулася в клініку зі скаргами на біль та обмеження рухів у правому колінному суглобі, часткову втрату опороздатності правої нижньої кінцівки. Вважає себе хворою близько 30 років, коли вперше стала відмічати біль у колінних суглобах. Останнім часом відмічає посилення больового синдрому та обмеження рухів у правому колінному суглобі. При зверненні проведено рентгенологічне дослідження, яке виявило ознаки двобічного гонартрозу 4 ст. (рис. 3a-б).

Рисунок 3 Хвора Л. Рентгенограми колінного суглоба до ендопротезування

а) пряма проєкція

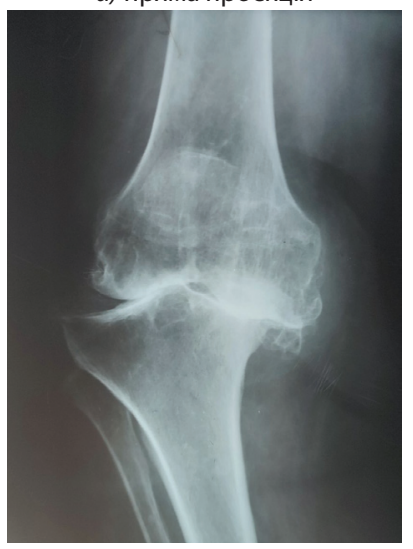

б) бокова проєкція

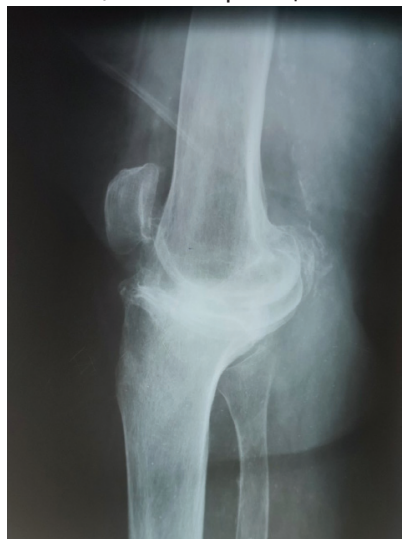

Рисунок 4 Хвора Л. Рентгенограми колінного суглоба, тотальне ендопротезування колінного суглоба із застосуванням тібіального подовжувача без збереження передньої хрестоподібної зв'язки

a) пряма проєкція

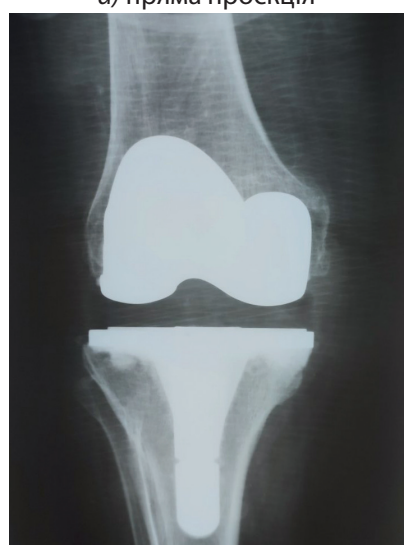

б) бокова проєкція

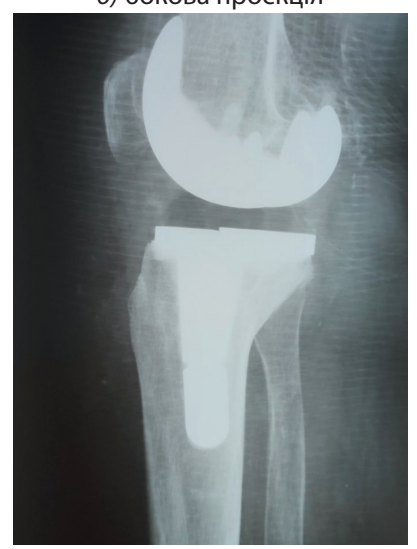

Рисунок 5 Хвора Н. Рентгенограми колінних суглобів до ендопротезування

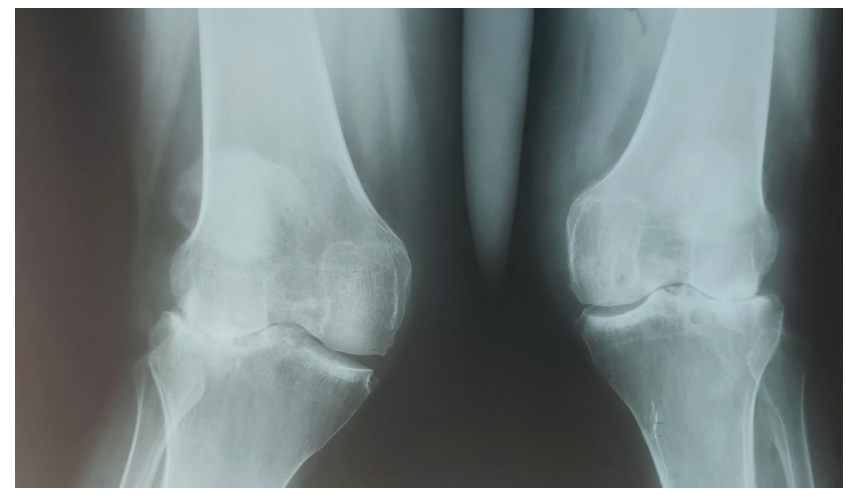

Рисунок 6 Хвора Н. Рентгенограма колінного суглоба, тотальне ендопротезування колінного суглоба без збереження передньої хрестоподібної зв'язки

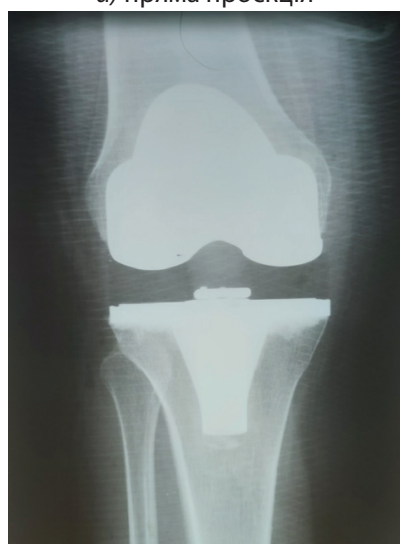

a) пряма проєкція б) бокова проєкція

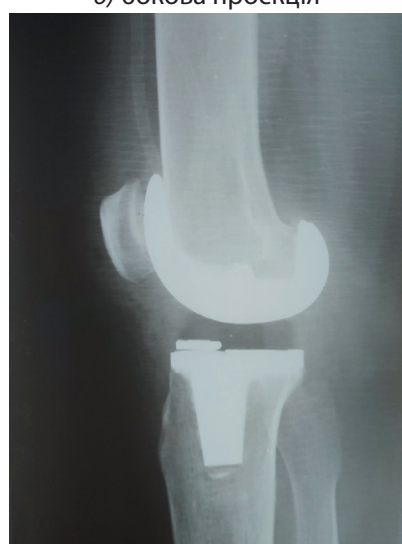

Встановлено діагноз: «Правобічний деформуючий гонартроз 4-ї ст. Варусна деформація правого колінного суглоба. Больовий синдром».

Хворій проведено тотальне ендопротезування правого колінного суглоба. Цементний тип фіксації з тібіальним подовжувачем (рис. 4a-б). Післяопераційна рана загоїлася первинно.

3 метою подальшого відновного лікування хвора переведена на амбулаторне лікування за місцем проживання.

\section{Клінічний випадок № 2}

Пацієнтка Н., 60 років. Звернулася в клініку зі скаргами на виражений біль, обмеження рухів та часткову втрату опороздатності правої нижньої кінцівки. При зверненні проведено рентгенологічне дослідження, яке виявило ознаки двобічного деформуючого гонартрозу 4-ї ст. Асептичний некроз латеральних виростків великогомілкової кістки (рис. 5).

Встановлено діагноз: «Двобічний деформуючий гонартроз 4-ї ст. Асептичний некроз латеральних виростків великогомілкової кістки. Вальгусна деформація обох колінних суглобів. Больовий синдром».

Хворій проведено тотальне ендопротезування правого колінного суглоба. Цементний тип фіксації (рис. 6 а-б). Післяопераційна рана загоїлася первинно.

3 метою подальшого відновного лікування хвора переведена на амбулаторне лікування за місцем проживання.

\section{Список використаної літератури}

1. Vina E.R., Kwoh C.K. (2018) Epidemiology of osteoarthritis: literature update. Curr. Opin. Rheumatol., 30(2): 160-167. doi: 10.1097/BOR.0000000000000479.

2. Palazzo C., Ravaud J.F., Papelard A. et al. (2014) The burden of musculoskeletal conditions. PLoS One, 9(3): e90633. doi:10.1371/journal.pone.0090633.

3. Nuesch E., Dieppe P., Reichenbach S. et al. (2011) All cause and disease specific mortality in patients with knee or hip osteoarthritis: population based cohort study. BMJ, 342: 1165. 
4. Breivik H., Collett B., Ventafridda V. et al. (2006) Survey of chronic pain in Europe: prevalence, impact on daily life, and treatment. Eur. J. Pain, 10(4): 287-333. doi: 10.1016/j. ejpain.2005.06.009.

5. Головач И.Ю. (2014) Остеоартрит: современные фундаментальные и прикладные аспекты патогенеза заболевания. Боль. Суставы. Позвоночник, 3(15).

6. Berenbaum F., Griffin T.M., Liu-Bryan R. (2017) Metabolic Regulation of Inflammation in Osteoarthritis. Arthritis Rheum., 69(1): 9-21.

7. Felson D.T. (2013) 0steoarthritis as a disease of mechanics. Osteoarthritis Cartilage, 21: 10-15. doi: 10.1016/j.joca.2012.09.012.

8. Corvol M.T., Malemud C.J., Sokoloff L. (1972) A pituitary growth promoting factor for articular chondrocytes in monolayer culture. Endocrinology, 90(1):262-271. doi: 10.1210/endo90-1-262.

9. Pelletier J.P., Roughley P.J., DiBattista J.A. et al. (1991) Are cytokines involved in osteoarthritic pathophysiology? Semin. Arthritis Rheum., 20(6 Suppl. 2): 12-25. doi:10.1016/00490172(91)90024-t.

10. Goldring M.B., Otero M. (2011) Inflammation in osteoarthritis. Curr. Opin. Rheumatol., 23(5): 471-478. doi: 10.1097/BOR.0b013e328349c2b1

11. Ayral X., Pickering E.H., Woodworth T.G. et al. (2005) Synovitis: a potential predictive factor of structural progression of medial tibiofemoral knee osteoarthritis: results of a 1 year longitudinal arthroscopic study in 422 patients. Osteoarthritis Cartilage, 13: 361-367.

12. Loeser R.F., Goldrina S.R., Scanzello C.R. et al. (2012) Osteoarthritis: A Disease of the Joint as an Organ. Arthritis Rheum., 64(6): 1697-1707.

13. Kim J.R., Yoo J.J., Kim H.A. (2018) Therapeutics in 0steoarthritis Based on an Understanding of Its Molecular Pathogenesis. Int. J Mol. Sci., 19(3): 674. doi:10.3390/ijms19030674.

14. Guilak F. (2011) Biomechanical factors in osteoarthritis. Best Pract. Res. Clin. Rheumatol., 25(6): 815-823. doi: 10.1016/j.berh.2011.11.013

15. Stevens A.L., Wishnok J.S., White F.M. et al. (2009) Mechanical injury and cytokines cause loss of cartilage integrity and upregulate proteins associated with catabolism, immunity, inflammation, and repair. Mol. Cell Proteomics, 8(7): 1475-1489.

16. Sharma V., Anuvat K., John L. et al. (2017) Scientific American Pain Management — Arthritis of the knee. Decker: Pain related disease states.

17. Тихилов Р.М., Корнилов Н.Н., Куляба Т.А. и др. (2014) Сравнительный анализ регистров эндопротезирования коленного сустава (обзор л-ры). Травматол. и ортопедия России, 2:112-121.

18. Bruyèreab 0 ., Honvoab G., Veronesec $\mathrm{N}$. et al. (2019) An updated algorithm recommendation for the management of knee osteoarthritis from the European Society for Clinical and Economic Aspects of Osteoporosis, Osteoarthritis and Musculoskeletal Diseases (ESCE0). Semin. Arthritis Rheum., 49(3): 337-350. doi: 10.1016/j.semarthrit.2019.04.008.

19. Shil'nikov V.A., Tikhilov R.M., Denisov A.0. (2008) Pain after total hip arthroplasty. Traumatology and Orthopedics of Russia, 2: 106-109.

20. Lee K., Goodman S.B. (2008) Current state and future of joint replacements in the hip and knee. Expert Rev. Med. Devices, 5(3): 383-393. doi: 10.1586/17434440.5.3.383.

21. Kurtz S. (2005) Prevalence of primary and revision total hip and knee arthroplasty in the United States from 1990 through 2002. JBJS Am., 87(7): 1487-1497.

22. Куляба Т.А., Корнилов Н.Н., Тихилов Р.М. и др. (2008) Эндопротезирование коленного сустава сиспользованием шарнирныхимплантатов. Травматология и ортопедия России, 2(48): 110-114.

23. Goodfellow J., O'Connor J. (1978) The mechanics of the knee and prosthesis design. Bone Joint Surg., 60(3): 358-369.

24. Heck D.A., Melfi C.A., Mamlin L.A. et al. (1998) Revision rates after knee replacement in the United. Med. Care., 36: 661-669.

25. Moreland J.R. (1988) Mechanisms of failure in total knee arthroplasty. Clin. Orthop.: 49-64.

\section{Відомості про авторів:}

Осадчук Тарас Іванович — кандидат медичних наук, лікар ортопед-травматолог вищої категорії, заслужений лікар України, старший науковий співробітник клініки ортопедії і травматології дорослих ДУ «Інститут травматології та ортопедії НАМН України», Київ, Україна.

Калашніков Андрій Валерійович - доктор медичних наук, професор, заслужений лікар України, керівник відділу травматичних пошкоджень опорно-рухового апарату та проблем остеосинтезу ДУ «Інститут травматології та ортопедії НАМН України», Київ, Україна.

Хиць Олександр Володимирович — лікар ортопед-травматолог КНП «Консультативно-діагностичний центр» Подільського району, Філія № 2, Київ, Україна.

Адреса для кореспонденції:

Осадчук Тарас Іванович

01601, Київ, вул. Бульварно-Кудрявська, 27

E-mail: osadchyktaras@ukr.net
26. Namba R., Graves S., Robertsson 0. et al. (2014) International comparative evaluation of knee replacement with fixed or mobile non-posterior-stabilized implants. J. Bone Joint Surg. Am., 96 (Suppl. 1.): 52-58.

27. Vaidya C., Alvarez E., Vinciguerra J. et al. (2011) Reduction of total knee replacement wear with vitamin E blended highly cross-linked ultra-high molecular weight polyethylene. Proc. Inst. Mech. Eng. H., 225(1): 1-7.

28. Essner A., Herrera L., Hughes P. et al. (2011) The influence of material and design on total knee replacement. J. Knee Surg., 24(1): 9-17.

29. Huj C., Salmon L., Maeno S. et al. (2011) Five-year comparison of oxidized zirconium and cobalt-chromium femoral components in total knee arthroplasty: a randomized controlled trial. J. Bone Join Surg. Am., 93(7): 624-630.

30. Veigl D., Vavř́k P., Pokorný D. et al. (2011) Comparison of in vivo characteristics of polyethylene wear particles produced by a metal and a ceramic femoral component in total knee replacement. Acta Chir. Orthop. Traumatol. Cech., 78(1): 49-55.

31. Browne J.A., Gall Sims S.E., Giuseffi S.A. et al. (2011) All-polyethylene tibial components in modern total knee arthroplasty. J. Am. Acad. Orthop. Surg., 19(9): 527-535.

32. Willing R., Kim I.Y. (2011) Design optimization of a total knee replacement for improved constraint and flexion kinematics. J. Biomech., 44(6): 1014-1020.

33. Guy S.P., Farndon M.A., Sidhom S. et al. (2012) Gender differences in distal femoral morphology and the role of gender specific implants in total knee replacement: A prospective clinical study. Knee, 19(1): 28-31.

34. Гайко Г.В., Заєць В.Б., Калашніков О.В. та ін. (2017) Хірургічне лікування хворих на гонартроз (огляд літератури, І частина). Вісник ортопедії, травматології та протезування, 1:56-60.

35. Гайко Г.В., Осадчук Т.І., Заєць В.Б. та ін. (2017) Диференційний підхід до ендопротезування колінного суглоба у хворих на гонартроз залежно від тяжкості ураження. Вісник ортопедії, травматології та протезування, 2: 59-66.

36. Калашніков А.В., Осадчук Т.І. (2019) Наш підхід до ендопротезування колінних суглобів у хворих на гонартроз. Проблеми травматології та остеосинтезу, 1-2 (15-16).

\section{Gonarthrosis: prevalence and differential approach to endoprosthesis}

\section{T.I. Osadchuk', A.V. Kalashnikov', O.V. Khyts ${ }^{2}$}

${ }^{1} \mathrm{SI}$ «Institute of Traumatology and Orthopedics of the NAMS of Ukraine», Kyiv, Ukraine

${ }^{2} \mathrm{CNE}$ «Consulting and Diagnostic Center» of the Podilsk district Branch № 2, Kyiv, Ukraine

Abstract. Gonarthrosis is one of the most actual and complex problems of modern orthopedics, affecting more than 250 million people worldwide, is the leading cause of severe pain in the elderly, leads to disability and is associated with an increased risk of death. At the present stage, total knee arthroplasty is the most effective and generally accepted method of treating gonarthrosis at the final stage of the disease. There are no other effective treatment for patients with osteoarthritis of the knee at this stage of the disease. The article considers the peculiarities of surgical treatment, the choice of endoprosthesis and presents our own experience of successful total knee arthroplasty in patients with gonarthrosis.

Key words: gonarthrosis, osteoarthritis, chronic pain syndrome, osteoarthritis, endoprosthesis, total endoprosthesis, arthroplasty, knee arthroplasty, arthrosis.

\section{Information about the authors:}

Osadchuk Taras I. - Candidate of Medical Sciences, Orthopedist-Traumatologist of the highest category, Honored Doctor of Ukraine, Senior Research Fellow of the Clinic of Orthopedics and Adult Traumatology, SI «Institute of Traumatology and Orthopedics of the NAMS of Ukraine», Kyiv, Ukraine.

Kalashnikov Andriy V. - Doctor of Medical Sciences, Professor, Honored Doctor of Ukraine, Head of the Department of Traumatic Musculoskeletal Injuries and Osteosynthesis Problems, SI «Institute of Traumatology and Orthopedics of the NAMS of Ukraine», Kyiv, Ukraine.

Khyts Olexandr V. - Orthopedist-Traumatologist, CNE «Consulting and Diagnostic Center» of the Podilsk district Branch № 2, Kyiv, Ukraine.

Address for correspondence:

Taras Osadchuk

01601, Kyiv, Bulvarno-Kudriavska str., 27

E-mail: osadchyktaras@ukr.net 